Ekuitas: Jurnal Pendidikan Ekonomi

Volume 7 Number 2 Tahun 2019, pp. 96-102

P-ISSN : 2354-6107 E-ISSN : 2549-2292

Open Access: https://ejournal.undiksha.ac.id/index.php/EKU

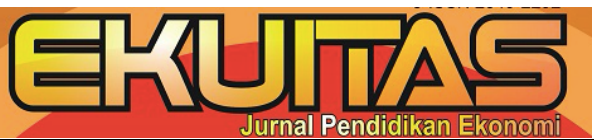

\title{
BERBISNIS ONLINE MELALUI MEDIA SOSIAL
}

\section{Andita Candra $\mathrm{W}^{*}$}

\section{STKIP PGRI Pasuruan}

\section{A R T I C L E I N F O}

Article history:

Received 08 July 2019

Received in revised form

8 Augustus 2019

Accepted 05 December

2019

Available online 11

December 2019

Kata Kunci:

Bisnis, Online, Media Sosial

Keywords:

Business, Online, Social

Media

\begin{abstract}
A B S T R A K
Artikel ini menyajikan hasil kajian dengan melihat fenomena banyaknya orang berjualan dilakukan melalui media masa dengan menggunakan jaringan internet yang sangat mudah untuk di lakukan. Tujuan karya ilmiah ini yaitu memberikan gambaran tentang bagaimana berbisnis melalui media masa yang kini marak digunakan khususnya para pemula yang memiliki jaringan terhubung dengan internet. Berawal dari jaringan yang sudah meluas, alangkah mudahnya kita memulai usaha melalui internet yang dapat menguntungkan kita sebagai pemula usaha. Usaha yang dilakukan bisa dipromosikan melalui internet dengan sangat mudah. Ada beberapa cara menjalankan bisnis online yaitu, melalui website, melalui blog, melalui jejaring sosial seperti facebook, twitter, instagram, dan terakhir melalui forum atau aplikasi jual beli seperti www.bukalapak.com, www.kaskus.co.id, www.berniaga.com, www.tokobagus.com, www.tokopedia.com, dan yang terakhir melalui aplikasi handphone seperti BBM, WhatssApp, Line, Kakaotalk, dan weChat.
\end{abstract}

\section{A B S T R A C T}

This article presents the results of the study by looking at the phenomenon of the large number of people selling through mass media using an internet network that is very easy to do. The purpose of this scientific work is to provide an overview of how to do business through mass media that is now widely used, especially beginners who have a network connected to the internet. Starting from a network that has expanded, it is easy for us to start a business through the internet that can benefit us as business beginners. The efforts made can be promoted through the internet very easily. There are several ways to run an online business, namely, through a website, through a blog, through social networks such as Facebook, Twitter, Instagram, and finally through forums or trading applications such as www.bukalapak.com, www.kaskus.co.id, www.berniaga .com, www.tokobagus.com, www.tokopedia.com, and the last through mobile applications such as BBM, WhatssApp, Line, Kakaotalk, and weChat.

Copyright (C) Ekuitas: Jurnal Pendidikan Ekonomi. All rights reserved.

\footnotetext{
* Coresponding author

Email : wahyuningtyasandita@yahoo.com (Andita Candra W)

$\underline{10.23887 / \text { ekuitas.v7i2.18197 }}$
} 


\section{PENDAHULUAN}

Berkembangnya teknologi kini yang semakin canggih memicu munculnya banyak jejaring sosial seperti, facebook, Line, twitter, dan instagram. Jejaring sosial ini tidak hanya di gunakan untuk menjalin pertemanan namun juga untuk berbisnis. Kini banyak orang yang memanfaatkan jejaring sosial untuk menjual produk produk meraka. Banyak orang yang tertarik berbelanja secara online karena tidak perlu pergi keluar rumah, terkena macet, dan kelelahan. Hanya perlu bertanya spesifikasi produk, memesan, membayar, kemudian barang akan diantar ke rumah.

Kegiatan ini merupakan sebuah peluang tersendiri untuk membuka bisnis secara online. Saat ini banyak toko grosir yang menjual pakaian harga grosir dengan hanya membeli secara ecer atau satuan. Kita dapat mencarinya dengan mudah di internet. Sehingga kita hanya perlu mempromosikan produknya dan memesan ketika ada orang yang membeli produk tersebut kepada kita. Sangat mudah dan bisa dilakukan oleh siapa saja. Bisnis online juga memiliki kekurangan diantaranya yaitu, masalah pembayaran bagi para awam, barang tidak sesuai dengan ekspetasi kita, masalah pengiriman tidak sesuai dengan alamat pembeli, penipuan/barang tidak dikirim.

\section{PEMBAHASAN}

Internet adalah jaringan-jaringan komputer yang saling terkoneksi satu sama lain. Internet memungkinkan orang-orang atau perusahaan-perusahaan di seluruh dunia untuk saling berkomunikasi suatu sama lain secara efektif dan murah. Sesuai dengan kepanjangannya, internet terdiri dari sekumpulan jaringan komputer milik perusahaan, institusi, lembaga pemerintah, ataupun penyedia jasa jaringan yang saling terhubung dimana masing-masing jaringan komputer yang dikelola secara independen. Penggunaan internet telah menjadi sebuah gaya hidup bagi sebagaian besar mahasiswa perguruan tinggi di seluruh dunia. Bagi mereka internet adalah sebuah alat fungsional yang telah mengubah cara seseorang berinteraksi dengan orang lain, maupun dalam menemukan informasi. Banyak diantara mahasiswa yang menggunakan internet untuk menyelesaikan berbagai kepentingan akademis, baik itu dilakukan melalui pertukaran e-mail dengan fakultas, teman sebaya, atapun kepentingan lainnya, termasuk melakukan bisnis online, baik itu sebagai penjual, reseller, maupun pembeli. Dengan kata lain seseorang yang memiliki akses internet dapat berkomunikasi langsung dengan seseorang yang lain, membuat informasi yang bermanfaat bagi orang lain, menemukan informasi-informasi yang disediakan orang lain atau menjual dan membeli produk-produk tertentu dengan biaya yang minimum dengan jaringan yang terhubung secara global. Dalam perkembangannya, internet mempunyai nilai bisnis antara lain:

a. Menghasilkan pendapatan baru dari penjualan online.

b. Mengurangi biaya transaksi melalui penjualan online dan dukungan pelanggan.

c. Menarik pelanggan baru melalui iklan dan pemasaran webserta penjualan on-line.

d. Meningkatkan loyalitas pelanggan saat ini melalui perbaikan dan dukungan.

1. Pengertian Bisnis Online

Bisnis berarti suatu organisasi yang menjual barang atau jasa kepada konsumen atau bisnis lainnya, untuk mendapatkan keuntungan atau laba. Kata bisnis dari bahasa Inggris yaitu business, dari kata dasar busy yang berarti "sibuk" dalam konteks individu, komunitas, ataupun masyarakat. Dalam artian, sibuk mengerjakan aktivitas dan suatu pekerjaan yang mendatangkan keuntungan.

Adapun bisnis online adalah bisnis yang dijalankan secara online yang menggunakan jaringan internet sedangkan informasi yang akan disampaikan atau dijual biasanya menggunakan media website, jejaring sosial dan forum jual beli.

Bisnis online dapat dilakukan dengan berbagai macam cara :

- Website

Website merupakan media online yang paling lama di gunakan untuk jual beli. Bagi orang awam pembuatan website ini biasanya di serahkan pada perusahaan atau perorangan yang menjual jasa pembuatan website. Harganya sangat variatif tergantung dengan jenis website yang di inginkan.

Bisnis online menggunakan website ini keutungannya terlihat lebih profesional namun karena pembuatan website membutuhkan biaya hal ini tidak disarankan untuk yang baru mau membuka bisnis online. Para pemula bisnis online sebaiknya menggunakan fasilitas gratis terlebih dahulu, seperti contoh yang akan di 
terangkan di bawah ini, sebelum memutuskan membuat website. Jika market sudah terbentuk, brand sudah dikenal dan mempunyai banyak pelanggan maka kita bisa memulai membuat website.

\section{- $\quad$ Blog}

Blog hampir mirip dengan website namun bisa kita buat secara gratis. Tampilan blog akan sangat tergantung pada kemampuan kita membuat blog. Kebanyakan toko online yang menggunakan blog tampilannya sangat cukup sederhana, hanya berupa gambar - gambar dan disusun secara vertikal. Tetapi ada juga beberapa toko online yang walaupun menggunakan blog tetapi tampilannya seperti website.

- Jejaring sosial :

Saat ini media yang paling populer untuk berbisnis online yaitu jejaring sosial. Berikut ini 3 jejaring sosial yang paling banyak digunakan untuk bisnis yaitu :

\section{Facebook}

Facebook adalah jejaring sosial yang paling banyak di gunakan orang untuk melakukan bisnis jual beli online. Jual beli di facebook dapat dilakukan melalui akun pribadi, group, maupun fasilitas fanspage (halaman) yang disediakan oleh facebook. Fanspage adalah yang paling cocok digunakan untuk jual beli dari pada 3 artenatif tersebut. Bisa dikatakan fanspage ini seperti sebuah toko, group seperti sebuah pasar, dan akun pribadi seperti sebuah rumah. Melihat hal ini kita dapat mengambil kesimpulan bahwa untuk terlihat profesional dan mempermudah bisnis kita dapat membuat fanspage, namun untuk promosi secara gratis kita dapat mengikuti forum jual beli yang ada di group. Selain itu sebenarnya facebook juga menyedikan layanan promosi fanspage, namun tentu saja ini tidak bisa di gunakan secara gratis. Kita harus membayar jika ingin dipromosikan oleh facebook.

\section{Twitter}

Twitter juga jejaring sosial yang marak digunakan untuk jual beli. Namun di twitter tidak ada fasilitas khusus untuk jual beli seperti di facebook, jadi kita hanya membuat akun baik pribadi maupun bisnis kemudian menawarkan produk yang kita punya dengan menguggah fotonya.

\section{Instagram}

Instagram adalah jejaring sosial yang saat ini sangat diminati untuk jual beli. Hal ini dikarenakan dalam instagram sperti ada dunia tersendiri. Disini ada akun bisnis yang biasanya orang melakukan berbagai cara untuk promosi, seperti : SFS (shout out for shout out) atau istilah indonesianya seperti barter promo, jadi kita mempromosikan akun instagram atau yang sering disebut IG milik orang lain. Selain SFS personal (antar 2 akun) ada juga SFS group, ini seperti promo berjamaah, beberapa akun membuat suatu gambar kemudian diketerangan gambar tersebut diisi identitas masing - masing akun. SFS ada yang gratis ada juga yang berbayar tergantung akun yang kita ajak SFS. Selain SFS ada juga endorse, ini merupakan jenis promosi dengan cara memberikan barang jualan kita kepada selebgram (selebritis instagram) kemudian akun selebgram akan menggunakan produk kita sambil mempromosikan baik mengunggah foto di instagram dengan memberi caption promosi barang yang di endorse maupun instastory di instagram.

Ada berbagai macam forum jual beli di dunia maya, beberapa diantaranya yang populer adalah :

1. berniaga.com

2. bukalapak.com

3. tokobagus.com

4. tokopedia.com

5. Shopee.com

Cara beriklan di forum jaul beli seperti di atas adalah dengan membuat akun dan mengunggah foto. Berjualan di forum jual beli tergolong efektif karena banyak orang yang melihat. Semua tergantung pada kata kunci yang kita gunakan diketerangan foto tersebut. Semakin bagus pilihan kata, semakin banyak orang yang dapat mengakses foto kita.
6. BBM (Blackberry Messenger)
7. WhatssApp
8. Line
9. Kakaotalk
10. weChat 
Kebanyakan dalam aplikasi tersebut ada fasilitas group sehingga kita bisa mengundang orang dan mempromosikan produk kita didalam group kepada orang - orang yang menjadi anggota group.

\section{Kelebihan dan kekurangan bisnis online}

\section{Kelebihan :}

1. Menjangkau pasar yang lebih luas dibandingkan dengan toko offline. Keuntungan yang kedua dari bisnis online yaitu, luasnya jangkauan pasar. Karena dengan jaringan internet, dapat membantu pemasaran bisnis yang dijalankan hingga mencakup semua daerah bahkan sampai ke berbagai negara lain. Yang dibutuhkan hanya optimalisasi menggunakan SEO, agar bisnis lebih mudah ditemukan konsumen.

2. Waktu kerja bisnis online yang tidak terbatas, bahkan nonstop 24 jam. Karena dalam melakukan bisnis online yang bekerja adalah sistem, sehingga tugas kita sebagai pemilik usaha hanya memberikan follow up atas permintaan yang telah diterima sistem.

3. Biaya operasional yang cenderung lebih murah dibandingkan bisnis offline. Bisnis online dapat dilakukan dari rumah bahkan dimana pun juga bisa, dan tidak terlalu membutuhkan biaya operasional yang terlalu tinggi layaknya bisnis offline.

4. Tidak membutuhkan modal usaha yang terlalu besar. Dalam menjalankan bisnis online, modal bukan hal yang utama bagi para pengusaha. Karena banyak peluang yang dapat dijalankan dengan modal kecil bahkan tanpa modal sama sekali, modal utama yang seharusnya dimiliki adalah fasilitas komputer atau laptop dan adanya jaringan internet

5. Memberikan keuntungan baik materi maupun non materi. Keuntungan materi yang diperoleh dari bisnis online tidak kalah besar dibanding dengan bisnis offline, karena biaya operasional bisnis online yang cenderung masih rendah. Selain itu juga ada keuntungan non materi dengan bertambah luasnya jaringan, juga sangat membantu perkembangan bisnis online yang dijalankannya.

6. Mudahnya pelayanan yang diberikan kepada para konsumen, dengan fasilitas online yang mendukung. Misalnya untuk pembayaran dapat dilakukan dengan mencantumkan nomor rekening perusahaan, sehingga hasil omset penjualan dapat langsung diterima.

Jika mencari bisnis yang murah, mudah, dan berpeluang besar, bisnis online dapat menjadi salah satu bisnis yang dapat dipilih.

\section{Kekurangan :}

1. Masalah pengiriman tidak sesuai dengan alamat pembeli.

Karena terkadang seseorang membeli suatu barang secara online tidak mempelajari alamat lengkap tujuan pengirimannya. Kalau membeli barang secara online hendaknya lebih teliti lagi sehingga tidak terjadi salah pengiriman.

2. Pembayaran.

Masalah pembayaran menjadi sesuatu yang membingungkan dan cukup menyulitkan bagi para orang awam. Belum lagi ketakutan bila pembayaran tidak terkirim maupun barang tidak diterma. Karena bisnis online kebanyakan tidak mempertemukan kedua belah pihak dalam proses transaksi jual beli barang. Dituntut kejujuran yang tinggi dalam proses bisnis online.

3. Barang tidak sesuai dengan ekspetasi kita.

Karena barang yang kita lihat hanya melalui layar, kebanyakan pada saat menerima barang tidak sesuai dengan yang aslinya. Contoh dalam hal seperti pakaian pada bisnis online kita tidak bisa merasakan bahan pakaian dan kadang juga ukuran pakaian tidak sesuai dengan tubuh kita. Hal - hal diatas merupakan sebagian dari kelebihan \& kelemahan bisnis online. Sekarang kita tinggal memilih, apakah ingin menjalankan usaha secara online maupun offline.

4. Masalah penipuan/barang tidak dikirim.

Sering terjadinya penipuan/barang tidak dikirim oleh penjual online. Kita sebagai pembeli harus mempelajari kinerja penjual online melalui respon-respon pelanggan atau testi yang biasanya tertera di halaman promosi penjual online. Ini juga dapat digunakan oleh penjual bisnis online, untuk menyediakan tempat bagi para pembeli untuk memberi respon yang dapat dibaca secara umum. Karena dengan responrespon pembeli yang baik, dapat meningkatkan reputasi penjual online hingga lebih terpercaya. 


\section{KESIMPULAN}

Dari pembahasan dapat kita simpulkan bahwa melalui internet kita dapat menambah pendapatan dengan cara berbisnis online. Saat ini bisnis online sedang sangat berkembang. Kita dapat ikut andil memanfaatkan bisnis online ini dengan menjual berbagai macam barang atau produk. Cara yang dilakukan dalam menjalankan bisnis online bisa melalui website, blog, forum jual beli, dan jejaring sosial, seperti facebook, Line, twitter, dan instagram. Beberapa kelebihan bisnis online yaitu, memberikan keuntungan baik materi maupun non materi. Keuntungan yang diperoleh dari bisnis online tidak kalah dibandingkan dengan bisnis offline, karena biaya operasional bisnis online yang cenderung masih rendah. Selain itu keuntungan non materi dengan bertambah luasnya jaringan, juga sangat membantu perkembangan bisnis online yang dijalankan, masalah pembayaran menjadi sesuatu yang membingungkan dan cukup menyulitkan. Belum lagi ketakutan bila pembayaran tidak terkirim maupun barang tidak diterima.

\section{DAFTAR PUSTAKA}

Sutrisno M, Putranto H. 2005. Teori-Teori Kebudayaan. Kanisius. Yogyakarta. Indonesia.

Suyanto M. Strategi Periklanan pada Perusahaan e-commerce Top Dunia. Andi Offset. Yogyakarta.

Indonesia. 2003. Tersedia pada URL: https://books.google.co.id/books?id=VRVPbZ0SasC. Akses 18 Mei 2017. Pawito. Penelitian Komunikasi Kualitatif. LkiS. Yogyakarta. Indonesia. 2008. Tersedia pada URLhttps://books.google.co.id/books?id=UfM33NzcHJsC. Akses 18 Mei 2017.

Somad R, Priansa D.J. 2014. Manajemen Komunikasi: Mengembangkan Bisnis Berorientasi Pelanggan. Penerbit Alfabeta. Bandung. Indonesia.

Daryanto, Rahardjo M. 2015 Teori Komunikasi. Gava Media. Indonesia. Yogyakarta. 